\title{
Culturable pathogenic bacteria in ticks parasitizing farm animals and rodents in Malaysia
}

\author{
Loong, S.K. ${ }^{1}$, Lim, F.S. ${ }^{1}$, Khoo, J.J. ${ }^{1}$, Lee, H.Y. ${ }^{2}$, Suntharalingam, C. ${ }^{3}$, Ishak, S.N. ${ }^{4}$, Mohd-Taib, F.S. ${ }^{4}$ and \\ AbuBakar, S. $1,2,5^{*}$ \\ ${ }^{1}$ Tick Cell Biobank Asia Outpost, Tropical Infectious Diseases Research \& Education Centre, \\ University of Malaya, 50603 Kuala Lumpur, Malaysia \\ ${ }^{2}$ Centre of Excellence for Vaccine \& Protein Therapeutics Process Development, Tropical Infectious Diseases \\ Research \& Education Centre, University of Malaya, 50603 Kuala Lumpur, Malaysia \\ ${ }^{3}$ Economics \& Social Science Research Centre, Malaysian Agricultural Research and Development Institute \\ (MARDI), 43400 Serdang, Malaysia \\ ${ }^{4}$ School of Environmental Science and Natural Resources, Faculty of Science and Technology, \\ Universiti Kebangsaan Malaysia, 43600 Bangi, Malaysia \\ ${ }^{5}$ Department of Medical Microbiology, Faculty of Medicine, University of Malaya, 50603 Kuala Lumpur, \\ Malaysia \\ *Corresponding author e-mail: sazaly@um.edu.my \\ Received 16 August 2019; received in revised form 16 December 2019; accepted 16 December 2019
}

\begin{abstract}
Ticks are vectors of bacteria, protozoa and viruses capable of causing serious and life threatening diseases in humans and animals. Disease transmission occurs through the transfer of pathogen from tick bites to susceptible humans or animals. Most commonly known tick-borne pathogens are obligate intracellular microorganisms but little is known on the prevalence of culturable pathogenic bacteria from ticks capable of growth on artificial nutrient media. One hundred and forty seven ticks originating from dairy cattle, goats and rodents were collected from nine selected sites in Peninsular Malaysia. The culture of surfacesterilized tick homogenates revealed the isolation of various pathogenic bacteria including, Staphylococcus sp., Corynebacterium sp., Rothia sp., Enterococcus faecalis, Klebsiella pneumoniae, Escherichia coli and Bacillus sp. and its derived genera. These pathogens are among those that affect humans and animals. Findings from this study suggest that in addition to the regular intracellular pathogens, ticks could also harbor extracellular pathogenic bacteria. Further studies, hence, would be needed to determine if these extracellular pathogens could contribute to human or animal infection.
\end{abstract}

\section{INTRODUCTION}

Ticks are blood feeding ectoparasites of numerous hosts, including farm animals such as cattle and goats, rodents, birds and reptiles (Liu \& Bonnet, 2014). They are also vectors of bacteria, protozoa and viruses capable of causing serious and life threatening diseases in humans and animals (Khoo et al., 2016; Bell-Sakyi et al., 2018). Amongst the bacterial species found within ticks, those in the genera of Rickettsia, Anaplasma, Coxiella and Ehrlichia that are commonly associated with human and animal infections (Khoo et al., 2016) are obligate intracellular pathogens incapable of growing on artificial nutrient culture. As disease transmission from ticks to humans occur through tick bites (Loong et al., 2018a), there is also risk of transmission of other pathogens carried within the ticks. To date, little is known on the prevalence of culturable pathogenic bacteria harbored within ticks. Bacterial culture and isolation are essential as they have long been accepted as the gold standard for laboratory confirmation of bacterial infections (Loong et al., 2016).

The recent economic trade expansion, surging human travel, ecohabitat changes and the increasing geographical distribution 
of several tick species have contributed to the emergence of tick-borne diseases (Liu \& Bonnet, 2014). Trading and importation of farm animals provide a conduit for the entry of pathogen-carrying ticks into the respective countries. Between 2012 and 2018, Malaysia continuously experienced a supply shortage of fresh milk and mutton (Department of Veterinary Services, 2018). To meet local demand for these livestock products, the government has encouraged import from other countries (Shahudin et al., 2018; Loong et al., 2019). As a result, the importation of non-native farm animals could inadvertently introduce potentially exotic diseases in addition to the common tick-borne pathogens into Malaysia's ecosystem. The coexistence of rodents in close proximity to animal and human habitations potentially promote the transmission of zoonotic pathogens, in particular tick-borne pathogens. Rodents play an important role in harboring and spreading (via ticks) of numerous tick-borne pathogens including Babesia microti, Borrelia burgdorferi, Rickettsia australis and Rickettsia rickettsii (Meerburg et al., 2009). Here, we present a baseline study of culturable bacterial pathogens of ticks recovered from dairy cattle, goat and rodent, collected from nine selected sites in Peninsular Malaysia.

\section{MATERIALS AND METHODS}

Parasitizing ticks were scoured from two types of farm animals (dairy cattle and goat) and rodents at multiple locations in Malaysia. The sampling of cow ticks was performed in three dairy cattle farms in Rantau and Mantin in Negeri Sembilan, and Banting in Selangor (Figure 1, Table 1). Ticks infesting on goats were collected from two farms in Teluk Intan and Bagan Datoh in Perak (Figure 1, Table 1). Meanwhile, ticks were collected off trapped rodents in the following sites in Selangor; Kampung Sungai Semungkis, Sungai Congkak, Ulu Perdik and Ulu Yam (Figure 1, Table 1). All ticks were stored in $70 \%$ ethanol prior to transportation to the laboratory for analyses. In the laboratory, collected ticks were surface sterilized with $70 \%$ ethanol and rinsed thoroughly with nuclease-free water to remove all possible environmental contaminants (Loong et al., 2018a). Adult ticks were then sorted according to species, host, sex and blood meal status into pools of between 1 and

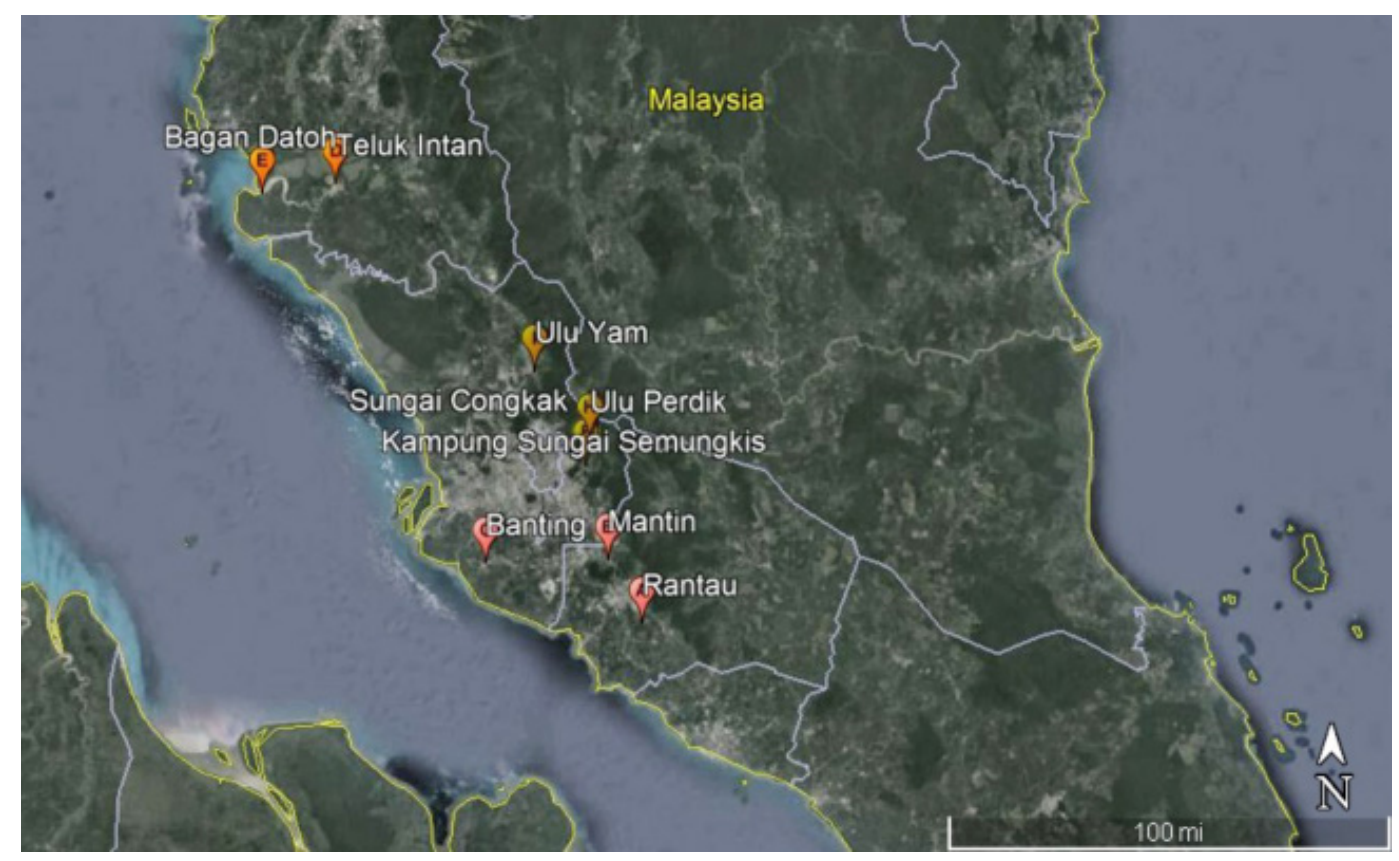

Figure 1. Sampling sites for the collection of ticks from farm animals and rodents. 
Table 1. Geographical coordinates of sampling sites in this study

\begin{tabular}{|c|c|c|c|c|}
\hline Sampling site & Latitude & Longtitude & No. of tick (n) & Animal host \\
\hline Rantau, Negeri Sembilan & $2.6200^{\circ} \mathrm{N}$ & $102.0033^{\circ} \mathrm{E}$ & 6 & Cow \\
\hline Mantin, Negeri Sembilan & $2.8230^{\circ} \mathrm{N}$ & $101.8942^{\circ} \mathrm{E}$ & 18 & \\
\hline Banting, Selangor & $2.8121^{\circ} \mathrm{N}$ & $101.5026^{\circ} \mathrm{E}$ & 14 & \\
\hline Teluk Intan, Perak & $4.0224^{\circ} \mathrm{N}$ & $101.0206^{\circ} \mathrm{E}$ & 25 & Goat \\
\hline Bagan Datoh, Perak & $3.9919^{\circ} \mathrm{N}$ & $100.7861^{\circ} \mathrm{E}$ & 14 & \\
\hline Kampung Sungai Semungkis, Selangor & $3.1258^{\circ} \mathrm{N}$ & $101.8232^{\circ} \mathrm{E}$ & 21 & Rodent \\
\hline Sungai Congkak, Selangor & $3.2087^{\circ} \mathrm{N}$ & $101.8435^{\circ} \mathrm{E}$ & 33 & \\
\hline Ulu Perdik, Selangor & $3.2052^{\circ} \mathrm{N}$ & $101.8359^{\circ} \mathrm{E}$ & 4 & \\
\hline Ulu Yam, Selangor & $3.4254^{\circ} \mathrm{N}$ & $101.6596^{\circ} \mathrm{E}$ & 12 & \\
\hline
\end{tabular}

Table 2. Blood meal status and sex of ticks collected from the different animal hosts in this study

\begin{tabular}{lcccccc}
\hline & \multicolumn{2}{c}{ Dairy cattle $(\mathrm{n}=38)$} & \multicolumn{2}{c}{ Goat $(\mathrm{n}=39)$} & \multicolumn{2}{c}{ Rodent $(\mathrm{n}=70)$} \\
\cline { 2 - 6 } & $\mathrm{F}$ & $\mathrm{M}$ & $\mathrm{F}$ & $\mathrm{M}$ & $\mathrm{F}$ & $\mathrm{M}$ \\
\hline Engorged $(\mathrm{n}=137)$ & 29 & 9 & 29 & 0 & 69 & 1 \\
Not engorged $(\mathrm{n}=10)$ & 0 & 0 & 5 & 5 & 0 & 0 \\
\hline
\end{tabular}

F, Female; M, Male.

5 individuals, before pulverization in liquid nitrogen using chilled mortar and pestle (Khoo et al., 2016). The resulting homogenates were cultured onto Columbia agar with 5\% sheep blood and incubated aerobically at $37^{\circ} \mathrm{C}$ for $48 \mathrm{~h}$. Bacterial cultures were streak-plated until single colonies were obtained and 16S rDNA sequencing was performed on the colonies to facilitate identification of the pathogen (Loong et al., 2016).

\section{RESULTS}

A total of 147 ticks were collected from dairy cattle, goats and rodents from nine selected locations in Peninsular Malaysia (Table 2). Amongst them, 132 were females, 15 were males and five of each were not engorged while 137 were engorged (Table 2). The majority of ticks were collected from rodents $(n=70)$, followed by goats $(n=39)$ and cattle $(\mathrm{n}=38)$ (Table 2). Sungai Congkak represented the location with the highest tick collection ( $\mathrm{n}=33$ ), whereas Ulu Perdik was the location with the least collected tick $(n=4)$, both from rodent hosts (Table 1$)$. The tick species which were determined using established morphological keys (Khoo et al., 2016), showed an almost homogenous disassociation between different hosts. Rhipicephalus microplus was found exclusively infesting dairy cattle, Haemaphysalis bispinosa solely on goats and, the majority of rodents with Ixodes granulatus and only one Dermacentor sp. was found on a Maxomys surifer rodent. The collected Dermacentor sp. could not be classified to the species level due to damaged gnathostome, crucial for tick species identification. I. granulatus was collected from six different rodent hosts $(M$. surifer, Maxomys whiteheadi, Sundamys muelleri, Rattus rattus, Rattus tiomanicus and Leopoldamys sabanus).

There were considerable genus and species diversity in the bacterial isolates cultured from the ticks. Bacteria from the genera Bacillus, Corynebacterium, Rothia and Staphylococcus were found in ticks collected from dairy cattle, with Staphylococcus chromogenes and Staphylococcus sciuri identified to the 
species level (Table 3). Meanwhile, ticks collected from goats yielded Bacillus sp., Enterococcus faecalis, Escherichia coli, Klebsiella pneumoniae and Lysinibacillus sp. (Table 4). The rodent ticks however, harbored bacteria closely related to the Bacillus genera. Amongst those cultured were Bacillus sp., Brevibacillus sp., Lysinibacillus sp. and Paenibacillus lautus (Table 5). Differences in the number of bacterial isolates were noted in the individual tick pools, some with up to three different isolated bacteria and some showing no bacterial growth. All specimens showing no bacterial growth were from pools of engorged females collected from cattle (2/45 pools) and rodents (18/45 pools), whereas pools of males (4/45 pools), irrespective of the blood meal status, spawned various bacterial isolates (Tables 3-5).

Table 3. Cultivable bacteria in ticks parasitizing dairy cattle

\begin{tabular}{|c|c|c|c|c|c|}
\hline $\begin{array}{l}\text { Pool \# } \\
\text { (individuals/ } \\
\text { pool, n) }\end{array}$ & Location & Tick species & $\begin{array}{l}\text { Tick } \\
\text { sex }\end{array}$ & $\begin{array}{l}\text { Blood } \\
\text { meal } \\
\text { status }\end{array}$ & Bacteria identity \\
\hline $1(n=3)$ & $\mathrm{RT}$ & R. microplus & $\mathrm{F}$ & $\mathrm{E}$ & $\begin{array}{l}\text { - Staplylococcus sp. } \\
\text { - Corynebacterium sp. } \\
\text { - Bacillus sp. }\end{array}$ \\
\hline $2(n=3)$ & $\mathrm{RT}$ & R. microplus & $\mathrm{F}$ & $\mathrm{E}$ & - Staplylococcus sp. \\
\hline $3(n=3)$ & MT & R. microplus & $\mathrm{F}$ & $\mathrm{E}$ & NIL \\
\hline $4(n=3)$ & MT & R. microplus & $\mathrm{F}$ & $\mathrm{E}$ & NIL \\
\hline $5(\mathrm{n}=4)$ & MT & R. microplus & M & $\mathrm{E}$ & - Staphylococcus sp. \\
\hline $6(n=4)$ & MT & R. microplus & $\mathrm{F}$ & $\mathrm{E}$ & - Staphylococcus chromogenes \\
\hline $7(n=4)$ & MT & R. microplus & $\mathrm{F}$ & $\mathrm{E}$ & - Staphylococcus sp. \\
\hline $8(n=5)$ & BT & R. microplus & $\mathrm{F}$ & $\mathrm{E}$ & - Staphylococcus sciuri \\
\hline $9(\mathrm{n}=4)$ & BT & R. microplus & $\mathrm{F}$ & $\mathrm{E}$ & $\begin{array}{l}\text { - Staphylococcus sp. } \\
\text { - Corynebacterium sp. }\end{array}$ \\
\hline $10(n=5)$ & BT & R. microplus & M & $\mathrm{E}$ & $\begin{array}{l}\text { - Rothia sp. } \\
\text { - Corynebacterium sp. }\end{array}$ \\
\hline
\end{tabular}

RT, Rantau; MT, Mantin; BT, Banting; F, Female; M, Male; E, Engorged; NIL, No bacterial growth.

Table 4. Cultivable bacteria in ticks parasitizing goats

\begin{tabular}{|c|c|c|c|c|c|}
\hline $\begin{array}{l}\text { Pool \# } \\
\text { (individuals/ } \\
\text { pool, n) }\end{array}$ & Location & Tick species & $\begin{array}{l}\text { Tick } \\
\text { sex }\end{array}$ & $\begin{array}{l}\text { Blood } \\
\text { meal } \\
\text { status }\end{array}$ & Bacteria identity \\
\hline $1(n=5)$ & $\mathrm{TI}$ & H. bispinosa & $\mathrm{F}$ & $\mathrm{E}$ & $\begin{array}{l}\text { - Enterococcus faecalis } \\
\text { - Klebsiella pneumoniae } \\
\text { - Bacillus sp. }\end{array}$ \\
\hline $2(\mathrm{n}=5)$ & $\mathrm{TI}$ & H. bispinosa & $\mathrm{F}$ & $\mathrm{E}$ & $\begin{array}{l}\text { - Enterococcus faecalis } \\
\text { - Klebsiella pneumoniae } \\
\text { - Escherichia coli }\end{array}$ \\
\hline $3(n=5)$ & $\mathrm{TI}$ & H. bispinosa & $\mathrm{F}$ & $\mathrm{X}$ & - Escherichia coli \\
\hline $4(n=5)$ & $\mathrm{TI}$ & H. bispinosa & $\mathrm{F}$ & $\mathrm{E}$ & $\begin{array}{l}\text { - Bacillus sp. } \\
\text { - Lysinibacillus sp. }\end{array}$ \\
\hline $5(n=5)$ & TI & H. bispinosa & M & $\mathrm{X}$ & - Bacillus sp. \\
\hline $6(\mathrm{n}=5)$ & $\mathrm{BD}$ & H. bispinosa & $\mathrm{F}$ & $\mathrm{E}$ & - Bacillus sp. \\
\hline $7(n=5)$ & $\mathrm{BD}$ & H. bispinosa & $\mathrm{F}$ & $\mathrm{E}$ & - Bacillus sp. \\
\hline $8(n=4)$ & $\mathrm{BD}$ & H. bispinosa & $\mathrm{F}$ & $\mathrm{E}$ & - Bacillus sp. \\
\hline
\end{tabular}

TI, Teluk Intan; BD, Bagan Datoh; F, Female; M, Male; E, Engorged; X, Not engorged. 
Table 5. Cultivable bacteria in ticks parasitizing rodents

\begin{tabular}{|c|c|c|c|c|c|c|}
\hline $\begin{array}{l}\text { Pool \# } \\
\text { (individuals/ } \\
\text { pool, n) }\end{array}$ & Location & Rodent host & Tick species & $\begin{array}{l}\text { Tick } \\
\text { sex }\end{array}$ & $\begin{array}{c}\text { Blood } \\
\text { meal } \\
\text { status }\end{array}$ & Bacteria identity \\
\hline $1(n=1)$ & $\mathrm{SC}$ & M. surifer & Dermacentor sp. & $\mathrm{F}$ & $\mathrm{E}$ & NIL \\
\hline $2(n=1)$ & $\mathrm{SC}$ & S. muelleri & I. granulatus & $\mathrm{F}$ & $\mathrm{E}$ & $\begin{array}{l}\text { - Bacillus sp. } \\
\text { - Brevibacillus sp. } \\
\text { - Lysinibacillus sp. }\end{array}$ \\
\hline $3(n=1)$ & $\mathrm{SC}$ & S. muelleri & I. granulatus & $\mathrm{F}$ & $\mathrm{E}$ & - Bacillus sp. \\
\hline $4(n=1)$ & $\mathrm{SC}$ & S. muelleri & I. granulatus & $\mathrm{F}$ & $\mathrm{E}$ & $\begin{array}{l}\text { - Bacillus sp. } \\
\text { - Brevibacillus sp. }\end{array}$ \\
\hline $5(n=1)$ & $\mathrm{SC}$ & S. muelleri & I. granulatus & M & $\mathrm{E}$ & $\begin{array}{l}\text { - Paenibacillus lautus } \\
\text { - Bacillus sp. } \\
\text { - Brevibacillus sp. }\end{array}$ \\
\hline $6(n=1)$ & $\mathrm{SC}$ & S. muelleri & I. granulatus & $\mathrm{F}$ & $\mathrm{E}$ & - Bacillus sp. \\
\hline $7(n=1)$ & $\mathrm{SC}$ & S. muelleri & I. granulatus & $\mathrm{F}$ & $\mathrm{E}$ & - Bacillus sp. \\
\hline $8(n=3)$ & $\mathrm{SC}$ & S. muelleri & I. granulatus & $\mathrm{F}$ & $\mathrm{E}$ & - Bacillus sp. \\
\hline $9(\mathrm{n}=3)$ & $\mathrm{SC}$ & S. muelleri & I. granulatus & $\mathrm{F}$ & $\mathrm{E}$ & NIL \\
\hline $10(n=3)$ & $\mathrm{SC}$ & S. muelleri & I. granulatus & $\mathrm{F}$ & $\mathrm{E}$ & NIL \\
\hline $11(n=2)$ & $\mathrm{SC}$ & S. muelleri & I. granulatus & $\mathrm{F}$ & $\mathrm{E}$ & NIL \\
\hline $12(n=2)$ & $\mathrm{SC}$ & R. rattus & I. granulatus & $\mathrm{F}$ & $\mathrm{E}$ & NIL \\
\hline $13(n=1)$ & $\mathrm{SC}$ & M. surifer & I. granulatus & $\mathrm{F}$ & $\mathrm{E}$ & NIL \\
\hline $14(n=4)$ & $\mathrm{SC}$ & S. muelleri & I. granulatus & $\mathrm{F}$ & $\mathrm{E}$ & NIL \\
\hline $15(n=5)$ & $\mathrm{SC}$ & S. muelleri & I. granulatus & $\mathrm{F}$ & $\mathrm{E}$ & NIL \\
\hline $16(n=3)$ & $\mathrm{SC}$ & S. muelleri & I. granulatus & $\mathrm{F}$ & $\mathrm{E}$ & NIL \\
\hline $17(n=4)$ & KSS & S. muelleri & I. granulatus & $\mathrm{F}$ & $\mathrm{E}$ & NIL \\
\hline $18(n=3)$ & KSS & S. muelleri & I. granulatus & $\mathrm{F}$ & $\mathrm{E}$ & NIL \\
\hline $19(n=3)$ & KSS & S. muelleri & I. granulatus & $\mathrm{F}$ & $\mathrm{E}$ & NIL \\
\hline $20(n=3)$ & KSS & S. muelleri & I. granulatus & $\mathrm{F}$ & $\mathrm{E}$ & - Bacillus sp. \\
\hline $21(n=2)$ & KSS & M. whiteheadi & I. granulatus & $\mathrm{F}$ & $\mathrm{E}$ & NIL \\
\hline $22(n=3)$ & KSS & S. muelleri & I. granulatus & $\mathrm{F}$ & $\mathrm{E}$ & - Lysinibacillus sp. \\
\hline $23(n=3)$ & KSS & L. sabanus & I. granulatus & $\mathrm{F}$ & $\mathrm{E}$ & NIL \\
\hline $24(n=4)$ & UP & R. tiomanicus & I. granulatus & $\mathrm{F}$ & $\mathrm{E}$ & NIL \\
\hline $25(n=4)$ & UY & S. muelleri & I. granulatus & $\mathrm{F}$ & $\mathrm{E}$ & NIL \\
\hline $26(n=4)$ & UY & S. muelleri & I. granulatus & $\mathrm{F}$ & $\mathrm{E}$ & NIL \\
\hline $27(n=4)$ & UY & S. muelleri & I. granulatus & $\mathrm{F}$ & $\mathrm{E}$ & NIL \\
\hline
\end{tabular}

SC, Sungai Congkak; KSS, Kampung Sungai Semungkis; UP, Ulu Perdik; UY, Ulu Yam; F, Female; M, Male; E, Engorged; NIL, No bacterial growth.

\section{DISCUSSION}

We employed a non-selective bacterial culture method in this study, previously shown to enable isolation of rare and pathogenic bacteria species from tick specimens such as Corynebacterium lactis (Lim et al., 2018) and P. lautus (Loong et al., 2018a). Even though no bacterial growth was observed for some tick specimens, we suggest that it was not due to the limitation of the agar culture media but the method employed for bacterial isolation (Stewart,
2012). Tick cell lines (Bell-Sakyi et al., 2018) could perhaps be useful for the cultivation of non-culturable bacterial pathogens. The simultaneous isolation of up to three different bacterial species in the collected tick specimens was not unexpected, since previous microbiome studies performed based on next generation sequencing technologies have identified up to hundreds of bacterial genera associated to a single or pooled tick specimens (Khoo et al., 2016; Trout Fryxell et al., 2016; Estrada-Peña et al., 2018; Lado et al., 2018). These microbiome 
studies have identified numerous tick-borne pathogens (i.e. Rickettsia and Anaplasma) as well as other bacteria which were endogenous to the tick itself, or may have originated from the environment or the animal skin microbiota or the host blood meal (Moreno et al., 2006; Van Treuren et al., 2015; Clow et al., 2018; Estrada-Peña et al., 2018). Despite alcohol washing, some of the bacteria may have survived, perhaps in crevices of the exoskeleton not reachable by the alcohol. Bacteria from the genera Staphylococcus, Bacillus, Corynebacterium, Klebsiella and Rothia, some of which isolated in this study, were reported across many tick species (Andreotti et al., 2011; Carpi et al., 2011; Tveten et al., 2013; Clow et al., 2018; Ruiling et al., 2019), suggesting that these bacteria may have a role in the biology of the tick or the transmission of tick pathogens. Staphylococcus and Corynebacterium were detected in the gut tissues of ticks in previous studies, suggesting that ticks may be vectors of these bacteria (Abraham et al., 2017). However, since these bacteria were not normally considered as tick pathogens, they were rarely studied. This study represents an attempt at culturing these tick-associated bacteria, which have only been identified molecularly from ticks in past studies.

Staphylococcal infections among farm animals have been intensively studied, particularly on methicillin-resistant $S$. aureus and other species that cause mastitis (Foster, 2012). Although we were unsurprised by the finding of Staphylococcus sp. in $R$. microplus ticks found on dairy cattle, we were confounded by their absence in goat ticks. Since most Staphylococcus sp. are innocuous commensals on livestock skin (Foster, 2012), one explanation could be that the culture methods used in this study favored pathogenic strains, evolutionaryprimed for survival over commensal species (Loong et al., 2018b). This was illustrated by the isolation of Corynebacterium sp., $S$. chromogenes and S. sciuri, all pathogenic bovine mastitis causing bacteria (Gonçalves et al., 2016; Khazandi et al., 2018), from $R$. microplus tick pools. Rothia sp. is another bacteria capable of causing tissue infection in young, immunocompetent human (Tomczak et al., 2013) found in one male cow tick pool. In Malaysia, the majority of goat farms are still poorly managed leading to lamentable hygiene conditions usually with swarms of flies (Shahudin et al., 2018; Lim et al., 2019). These flies that are drawn to the faeces can then transmit the goat's gut bacteria to other areas (Ranjbar et al., 2016). This could explain the discovery of E. coli, E. faecalis and K. pneumoniae, all members of the goat gut microflora (Kim et al., 2017) and also potential human pathogens (Tian et al., 2018), in H. bispinosa ticks collected from the body of goats. $I$. granulatus ticks collected from rodents however, yielded only bacteria from the Bacillus and Bacillus-derived genera. Bacillus sp. and Lysinibacillus sp. were also found among ticks collected from dairy cattle and goats. This observation is in agreement with an earlier study that found bacteria from the genus Bacillus being the most dominant genus isolated from Ixodes ticks in the United States (Martin \& Schmidtmann, 1998). The predominance of these bacterial genera (Bacillus and Bacillus-derived genera) to environmental niches suggests that the isolated bacteria presumably originated from the environment too (Mukhtar et al., 2018). This finding should not be downplayed regardless, as environment-associated Bacillus sp. appears to have pathogenic potential in humans (Loong et al., 2017).

In conclusion, findings of the current study convey the impression that in addition to common intracellular tick-borne pathogens such as the rickettsial agents, other extracellular bacterial pathogens associated with human or animal infections could also be recovered and this provide a baseline information of the culturable bacterial species in ticks of farm animals and rodents. This study represents an attempt in culturing these tick-associated extracellular bacteria, which provides the opportunity for future research in determining their roles in tick biology and the transmission of pathogens by ticks, also highlighting the importance of considering other potential pathogens carried within ticks. 
Acknowledgements. We acknowledge the funding from the Ministry of Education, Malaysia for niche area research under the Higher Institution Centre of Excellence (HICoE) program (Project MO002-2019). This study was also supported in parts by research grants from the University of Malaya, Malaysia, under the Research University grant (RU008-2018) and the UMCoE Top 100 research grant (UM.00000188/HGA.GV).

\section{REFERENCES}

Abraham, N.M., Liu, L., Jutras, B.L., Yadav, A.K., Narasimhan, S., Gopalakrishnan, V., Ansari, J.M., Jefferson, K.K., Cava, F., Jacobs-Wagner, C. \& Fikrig, E. (2017). Pathogen-mediated manipulation of arthropod microbiota to promote infection. Proceedings of the National Academy of Sciences USA 114(5): E781E790.

Andreotti, R., Pérez de León, A.A., Dowd, S.E., Guerrero, F.D., Bendele, K.G. \& Scoles, G.A. (2011). Assessment of bacterial diversity in the cattle tick Rhipicephalus (Boophilus) microplus through tagencoded pyrosequencing. BMC Microbiology 11(1): 6 .

Bell-Sakyi, L., Darby, A., Baylis, M. \& Makepeace, B.L. (2018). The Tick Cell Biobank: A global resource for in vitro research on ticks, other arthropods and the pathogens they transmit. Ticks and Tick-borne Diseases 9(5): 1364-1371.

Carpi, G., Cagnacci, F., Wittekindt, N.E., Zhao, F., Qi, J., Tomsho, L.P., Drautz, D.I., Rizzoli, A. \& Schuster, S.C. (2011). Metagenomic profile of the bacterial communities associated with Ixodes ricinus ticks. PLoS One 6(10): e25604.

Clow, K.M., Weese, J.S., Rousseau, J. \& Jardine, C.M. (2018). Microbiota of field-collected Ixodes scapularis and Dermacentor variabilis from eastern and southern Ontario, Canada. Ticks and Tick-borne Diseases 9(2): 235-244.
Department of Veterinary Services. (2018). Perangkaan Ternakan 2017/2018. (http:/ /www.dvs.gov.my/index.php/pages/view/ 2234, accessed 5 January 2019).

Estrada-Peña, A., Cabezas-Cruz, A., Pollet, T. Vayssier-Taussat, M. \& Cosson, J.F. (2018). High throughput sequencing and network analysis disentangle the microbial communities of ticks and hosts within and between ecosystems. Frontiers in Cellular and Infection Microbiology 8: 236.

Foster, A.P. (2012). Staphylococcal skin disease in livestock. Veterinary Dermatology 23: 342-e63.

Gonçalves, J.L., Tomazi, T., Barreiro, J.R., Beuron, D.C., Arcari, M.A., Lee, S.H., Martins, C.M., Araújo Junior, J.P. \& dos Santos, M.V. (2016). Effects of bovine subclinical mastitis caused by Corynebacterium spp. on somatic cell count, milk yield and composition by comparing contralateral quarters. Veterinary Journal 209: 87-92.

Khazandi, M., Al-Farha, A.A., Coombs, G.W., O’Dea, M., Pang, S., Trott, D.J., Aviles, R.R., Hemmatzadeh, F., Venter, H., Ogunniyi, A.D., Hoare, A., Abraham, S. \& Petrovski, K.R. (2018). Genomic characterization of coagulase-negative staphylococci including methicillin-resistant Staphylococcus sciuri causing bovine mastitis. Veterinary Microbiology 219: 17-22.

Khoo, J.J., Chen, F., Kho, K.L., Ahmad Shanizza, A.I., Lim, F.S., Tan, K.K., Chang, L.Y. \& AbuBakar, S. (2016). Bacterial community in Haemaphysalis ticks of domesticated animals from the Orang Asli communities in Malaysia. Ticks and Tick-borne Diseases 7(5): 929-937.

Kim, S., Covington, A. \& Pamer, E.G. (2017). The intestinal microbiota: Antibiotics, colonization resistance, and enteric pathogens. Immunological Reviews 279(1): 90-105. 
Lado, P., Qurollo, B., Williams, C., Junge, R. \& Klompen, H. (2018). The microbiome of Haemaphysalis lemuris (Acari: Ixodidae), a possible vector of pathogens of endangered lemur species in Madagascar. Ticks and Tick-borne Diseases 9(5): 1252-1260.

Lim, F.S., Khoo, J.J., Akhavanrezeai, M., Loong, S.K., Khor, C.S. \& AbuBakar, S. (2019). Detection of Theileria luwenshuni from ticks infesting goats in Malaysia. Systematic \& Applied Acarology 24(10): 1971-1974.

Lim, F.S., Loong, S.K., Khoo, J.J., Tan, K.K., Zainal, N., Abdullah, M.F., Khor, C.S. \& AbuBakar, S. (2018). Identification and characterization of Corynebacterium lactis isolated from Amblyomma testudinarium of Sus scrofa in Malaysia. Systematic \& Applied Acarology 23(9): 1838-1844.

Liu, X.Y. \& Bonnet, S.I. (2014). Hard tick factors implicated in pathogen transmission. PLoS Neglected Tropical Diseases 8(1): e2566.

Loong, S.K., Ishak, S.N., Lim, F.S., Khoo, J.J., Tan, S.N., Freddy-Jalin, E.J., MohdTaib, F.S. \& AbuBakar, S. (2018a). Paenibacillus lautus, an opportunistic bacterial pathogen, isolated from Ixodes granulatus Supino (Acari: Ixodidae) collected from a Müller's giant Sunda rat (Sundamys muelleri). Systematic \& Applied Acarology 23(4): 597-602.

Loong, S.K., Khor, C.S., Jafar, F.L. \& AbuBakar, S. (2016). Utility of $16 \mathrm{~S}$ rDNA sequencing for identification of rare pathogenic bacteria. Jourmal of Clinical Laboratory Analysis 30: 1056-1060.

Loong, S.K., Lee, H.Y., Khoo, J.J., Lim, F.S., Ahmad-Nasrah, S.N., Azman, A.S., Suntharalingam, C., Panchadcharam, C. \& AbuBakar, S. (2019). Microbiological analysis of raw milk unveiled the presence of a dairy contaminant, Corynebacterium lipophiloflavum. Journal of Applied Biology \& Biotechnology 7(5): 41-44.
Loong, S.K., Mohammad-Wali, H.A., Che Mat Seri, N.A.A., Mahfodz, N.H., MohdGhazali, D., Wong, P.F. \& AbuBakar, S. (2018b). Effectiveness of sentinel rodents for surveillance of exposure to undocumented bacterial pathogens in animal research facility. Thai Journal of Veterinary Medicine 48(4): 671-679.

Loong, S.K., Teoh, B.T., Johari, J., Khor, C.S., Abd-Jamil, J., Nor'e, S.S., Samsudin, N.I., Azizan, N.S., Yaacob, C.N., CheMatSeri, A.A., Mahfodz, N.H. \& AbuBakar, S. (2017). Penicillin-susceptible, oxidasenegative, nonhemolytic, nonmotile Bacillus megaterium in disguise of Bacillus anthracis. Case Reports in Infectious Diseases 2017: 2578082.

Martin, P.A.W. \& Schmidtmann, E.T. (1998). Isolation of aerobic microbes from Ixodes scapularis (Acari: Ixodidae), the vector of Lyme disease in the eastern United States. Biological and Microbial Control 91(4): 864-868.

Meerburg, B.G., Singleton, G.R. \& Kijlstra, A. (2009). Rodent-borne diseases and their risks for public health. Critical Reviews in Microbiology 35(3): 221-270.

Moreno, C.X., Moy, F., Daniels, T.J., Godfrey, H.P. \& Cabello, F.C. (2006). Molecular analysis of microbial communities identified in different developmental stages of Ixodes scapularis ticks from Westchester and Dutchess Counties, New York. Environmental Microbiology 8(5): 761-772.

Mukhtar, S., Mehnaz, S., Mirza, M.S., Mirza, B.S. \& Malik, K.A. (2018). Diversity of Bacillus-like bacterial community in the rhizospheric and non-rhizospheric soil of halophytes (Salsola stocksii and Atriplex amnicola), and characterization of osmoregulatory genes in halophilic Bacilli. Canadian Journal of Microbiology 64(8): 567-579. 
Ranjbar, R., Izadi, M., Hafshejani, T.T. \& Khamesipour, F. (2016). Molecular detection and antimicrobial resistance of Klebsiella pneumoniae from house flies (Musca domestica) in kitchens, farms, hospitals and slaughterhouses. Journal of Infection and Public Health 9(4): 499-505.

Ruiling, Z., Zhendong, H., Guangfu, Y. \& Zhong, Z. (2019). Characterization of the bacterial community in Haemaphysalis longicormis (Acari: Ixodidae) throughout developmental stages. Experimental and Applied Acarology 77(2): 173-186.

Shahudin, M.S., Ghani, A.A.A., Zamri-Saad, M., Zuki, A.B., Abdullah, F.F.J., Wahid, H. \& Hassim, H.A. (2018). The necessity of a herd health management programme for dairy goat farms in Malaysia. Pertanika Journal of Tropical Agricultural Science 41(1): 1-18.

Stewart, E.J. (2012). Growing unculturable bacteria. Journal of Bacteriology 194(16): 4151-4160.

Tian, L., Sun, Z. \& Zhang, Z. (2018). Antimicrobial resistance of pathogens causing nosocomial bloodstream infection in Hubei Province, China, from 2014 to 2016: a multicenter retrospective study. BMC Public Health 18(1): 1121.
Tomczak, H., Bilska-Stoklosa, J., Osmola, K. Marcinkowski, M., Blażejewska, W. Myczko, K., Mańkowski, B. \& Kaczmarek, I. (2013). Rothia mucilaginosa, rarely isolated pathogen as an etiological factor of infection of soft tissues in young, healthy woman. Postepy higieny $i$ medycyny doświadczalnej 67: 1-5.

Trout Fryxell, R.T. \& DeBruyn, J.M. (2016). The microbiome of Ehrlichia-infected and uninfected Lone Star ticks (Amblyomma americanum). PLoS One 11(1): e0146651.

Tveten, A.K., Riborg, A. \& Vadseth, H.T. (2013). DGGE identification of microorganisms associated with Borrelia burgdorferi Sensu Lato- or Anaplasma phagocytophilum-infected Ixodes ricinus ticks from northwest Norway. International Journal of Microbiology 2013: 805456.

Van Treuren, W., Ponnusamy, L., Brinkerhoff, R.J., Gonzalez, A., Parobek, C.M., Juliano, J.J., Andreadis, T.G., Falco, R.C., Ziegler, L.B., Hathaway, N., Keeler, C., Emch, M., Bailey, J.A., Roe, R.M., Apperson, C.S., Knight, R. \& Meshnick, S.R. (2015). Variation in the microbiota of Ixodes ticks with regard to geography, species, and sex. Applied and Environmental Microbiology 81(18): 6200-6209. 